\title{
Figures and Institutions of the neurological sciences in Paris from 1800 to 1950: Part III: Neurology
}

\section{Les figures et institutions des sciences neurologiques à Paris de 1800 à 1950. Partie III: Neurologie}

\author{
Emmanuel Broussolle1, Jacques Poirier2, François Clarac3, Jean-Gaël Barbara4 \\ 1 : Université Claude Bernard Lyon I ; Hospices Civils de Lyon, Hôpital Neurologique Pierre Wertheimer, Service de \\ Neurologie C ; CNRS UMR 5229, Centre de Neurosciences Cognitives ; Lyon, France \\ 2 : Professeur Honoraire, Hôpital Pitié-Salpêtrière ; Paris, France \\ 3 : CNRS, UMR 6196, Laboratoire Plasticité et Phyisiopathologie de la motricité, Université Aix-Marseille II, Marseille, \\ France \\ 4 : CNRS, UMRS 7102, Laboratoire de neurobiologie des processus adaptatifs ; Université Pierre et Marie Curie ; CNRS \\ UMR 7219, Laboratoire SPHERE, Université Denis Diderot ; Paris, France
}

Correspondance : Pr. Emmanuel Broussolle, Service de Neurologie C, Hôpital Neurologique Pierre Wertheimer, 69677, Bron Cedex, FranceFrance

Email : emmanuel.broussolle@chu-lyon.fr

Key words : History, Paris, Neurosciences, Anatomy, Physiology, Neurology, Psychiatry, Psychology Mots-clés : histoire, Paris, neurosciences, anatomie, physiologie, neurologie, psychiatrie, psychologie

\begin{abstract}
We present a short historical review on of the major institutions and figures that contributed to make Paris a renowned centre of physiology and neurology during the XIXth and the first half of the XXth century. We purposely chose to focus on the period 1800-1950, as 1800 corresponds to the actual beginning of neurosciences, and 1950 marks their exponential rise. Our presentation is divided into four chapters, matching the main disciplines that which have progressed and contributed the most to the knowledge we have of the brain sciences: anatomy, physiology, neurology, and psychiatry-psychology. The present article is the third of the four parts of this review, which deals with the chapter onand is about deals with neurology. A special account credit should be given to Jean-Martin Charcot who founded the Salpêtrière School of neurology and became one of the world's most important world neurologists of the XIXth century. We provide below the biographical sketches of Armand Trousseau, Guillaume Benjamin Amand Duchenne, Jean-Martin Charcot, Alfred Vulpian, Désiré-Magloire Bourneville, Paul Richer, Henri Parinaud, Albert Pitres, Jules Joseph Dejerine, Mrs. Augusta Dejerine-Klumpke, Edouard Édouard Brissaud, Pierre Marie, Georges ÉEdouard Brutus Gilles de la Tourette, Joseph Babinski, André Thomas, Goeorges Marinesco, Achille Alexandre Souques, Geoerges Guillain and Charles Foix.
\end{abstract}

\section{Résumé}

Nous présentons une revue générale historique brève sur les principales institutions et personnalités ayant contribué à faire de Paris un centre renommé de physiologie et de neurologie au cours du XIXe siècle et de la première partie du XXe siècle. La raison du choix de cette période allant de 1800 à 1950 s'explique par le fait que 1800 marque les débuts des neurosciences, et 1950 leur développement exponentiel. Notre présentation est divisée en quatre chapitres, correspondant aux principales disciplines ayant progressé et contribué le plus 
aux connaissances que nous avons sur les sciences du cerveau : anatomie, physiologie, neurologie, et psychiatrie-psychologie. Le présent article est la troisième des quatre parties de cette revue générale, qui porte sur le chapitre de la neurologie. Une mention particulière doit être faite à Jean-Martin Charcot qui fut le fondateur de l'ÉEcole de Neurologie de la Salpêtrière et fut l'un des plus célèbres neurologues au monde du XIXe siècle. Nous présentons ci-après les biographies résumées de Armand Trousseau, Guillaume Benjamin Amand Duchenne, Jean-Martin Charcot, Alfred Vulpian, Désiré-Magloire Bourneville, Paul Richer, Henri Parinaud, Albert Pitres, Jules Joseph Dejerine, Mrs. Augusta DejerineKlumpke, ÉEdouard Brissaud, Pierre Marie, Georges ÉEdouard Brutus Gilles de la Tourette, Joseph Babinski, André Thomas, Goeorges Marinesco, Achille Alexandre Souques, Geoerges Guillain, et Charles Foix.

\section{Introduction}

During the 19th c. XIXth and early 20th c. XXth centuries, clinicians, anatomists and pathologists performed a considerable work as regards neurology. Numerous authors from many parts of the world contributed to the development of this new discipline. A special account should be credited should be given to to German speaking universities from Central Europe, institutions in Great Britain and North America, French and Italian neurological schools, and also medical universities from Belgium, the Netherlands, Scandinavia, Southern Europe, Russia and South America.

The purpose of the present article is to highlight the role of several physicians from Paris to the build-up of neurology. Of particular importance is Tthe emblematic Jean-Martin Charcot (1825-1893) is of particular importance, as hewho left his mark on French Neurology and became one of the most important world neurologists of the XIXth century. His works at the Salpêtrière hospital (Figure 1), the lectures he regularly gave, the renowned patients he treated, and his mundane activities made him a man "du tout Paris" (Parisian smart set). By When describing his work, one takes the full measure of the international impact the Salpêtrière School of Neurology and of the international impact it had at that time (Bogousslavsky, 2011). We wish now to present below - without being exhaustive - a biographical sketch of the most important masters who contributed to the reputation of Paris neurology.

\section{Armand TROUSSEAU (1801-1867)}

Trousseau (Figure 2) began his medical studies in his native city of Tours under the guidance of Pierre Bretonneau (1778-1862) (Bariéty, 1967; Lyons, 1976; Mayer, 1957; Pearce, 2002a; Peumery, 2003). Together with Bretonneau and Alfred Velpeau (1795-1867), they founded the medical school of Tours. Trousseau continued his studies in Paris and became a docteur en médeicine (M.D.) in 1825. He was successively appointed professeur agrégé (1827), médecin des hôpitaux de Paris (1830) and professor of therapeutics (1839). He acceded to the chair of Clinique Médicale (Clinical Medicine) at the Hôtel-Dieu hospital in 1852 and was elected at the Académie de médecine (French National Academy of Medicine) in 1856. With his student Hermann Pidoux (1808-1882), Hhe wrote Traité de thérapeutique et matière médicale (Treatise on Therapeutics) in 18365 with his student Hermann Pidoux (1808-1882) (Trousseau and Pidoux, 1836), and then with Belloc Traité pratique de la phtisie laryngée, de la laryngite chronique et des maladies de la voix (A Ppractical Ttreatise on Llaryngeal Pphthisis, Cchronic 1Laryngitis, and Ddiseases of the Vvoice, 1837), on his own. (Trousseau and Belloc, 1837). Trousseau recommended and practised tracheotomy in croup and thoracocentesis in pleural effusion. His Cliniques médicales de l'Hôtel-Dieu (Lectures on Cclinical Mmedicine, delivered at the Hôtel-Dieu, Paris, 1861), in which Trousseau made 
several and greatly accurate clinical descriptions of neurological syndromes such as aphasia (Lebrun, 1993), tetany (Trousseau sign), movement disorders and tics, have been translated and re-edited many times (Trousseau, 1861; Rickards et al., 2010).

\section{Guillaume Benjamin Amand DUCHENNE (1806-1875)}

Duchenne, also known as Duchenne de Boulogne (Figure 3), did his medical studies in Paris, then came back to work in his native town of Boulogne, and thereafter moved back again to Paris for familial reasons (Borg, 1992; Clarac et al., 2009; Cuthbertson, 1979; Jay, 1998; Parent, 2005a, 2005b; Pearce, 1999; Rondot, 2005). In order to relieve his the patients' pain, he took an interest in electropuncture, but realized that this method was especially useful for analyzing the most complex muscle contractions. Without receiving any advice, he went around the Parisian hospitals "with an electric box and a battery" and two rheophores (electrodes) to cause perform a very specific stimulation patterns (?) in patients.

He bonded with Trousseau at the Hôtel-Dieu hospital, with Pierre François Olive Rayer (1793-1867) at the Charité hospital and - above all - with Charcot, who received him at the Salpêtrière hospital and on whom he had a great influence. His procedures on localized electrical stimulation with faradic current were published at the Académie des Sciences (French Academy of Sciences) in 1847. Using this technique as well as muscle biopsy, Duchenne thus described numerous neuromuscular pathologies (Nelson and Genain, 1989; Reincke and Nelson, 1990). In 1861 he commented on the medical history of a young boy suffering from congenital hypertrophic paraplegia and described it with more accuracy in 1868 (Duchenne, 1868; Brody and Wilkins, 1868), coining and coined the term "pseudohypertrophic muscular dystrophy" for this pathology "pseudohypertrophic muscular dystrophy", known today as Duchenne muscular dystrophy. As early as 1850 - at the same time as François Amilcar Aran (1817-1861) - he studied progressive muscular atrophy (later to be named Aran-Duchenne syndrome) and distinguished it from other paralyses ? (pluriel) In 1858 Duchenne described a type of progressive locomotor ataxia, better known today as tabes dorsalis or neurosyphilis, thanks to the reference work of Moritz Heinrich Romberg (1795-1873) (Duchenne, 1858).

Duchenne contributed in quite an original way to the analysis of the muscles involved in facial expressions and drew a complete explanation of emotions out of it (Cuthbertson, 1985; Duchenne, 1862b; Hueston and Cuthbertson, 1978). Few were interested in his results in France, whereas in England Charles Robert Darwin (1809-1882) used used photographs from Duchenne in his book The Expression of the Emotions in Man and Animals published in 1874 (Darwin, 1874). Duchenne developed a passion for photography from the very beginning of his career (Cuthbertson and Hueston, 1979). He used collodion negatives and albumen prints. He photographed all the effects of electrical stimulation with faradic current of the facial muscles as well as the pathological responses and put them together in an album published in 1862 (Figure 2 34) (Duchenne, 1862a). He also made microscope photographs and produced a detailed atlas of the human brainstem that he presented at the Académie Nationalde de Médecine in 1869. He published two major works on muscular activity : De l'électrisation localisée et son application à la physiologie, à la pathologie et à la thérapeutique (A Treatise on Llocalized eElectrization) in 1855 (Duchenne, 1855) and his major book Physiologie des mouvements démontrée à l'aide de l'expérimentation électrique et de l'observation clinique et applicable à l'étude des paralysies et des déformations (Physiology of Mmotion Ddemonstrated by Mmeans of Eelectrical sStimulation and cClinical Oobservation and Aapplied to the sStudy of Pparalysis and Ddeformities) in 1867 (Duchenne, 1867; Ostini, 1993). Of particular interest Iin this book, is the description of focal spasms such as the 
writer's cramp and musician cramps is of particular interest as well as the description of other focal spasms (which are currently described as examples of task-specific dystonias).

Jean-Martin CHARCOT (1825-1893)

Charcot (Figure 4) is universally recognized as the founder of French neurology (Clanet, 2008; Gelfand et al., 1996; Goetz et al., 1995; Massie, 2004; Tan and Shigaki, 2007; Wechsler, 1953). He was a médecin des hôpitaux de Paris and headed a department at the Salpêtrière hospital in 1862, at the same time as his friend Alfred Vulpian. He succeeded Vulpian as a professor of pathology at the Faculty of Medicine of Paris in 1872 and then became the first professor holding to hold the chair of the diseases of the nervous system, created for him at the Salpêtrière hospital in 1882. He was a member of the Académie Nationalde de Médecine and of the Académie des sciences (1883). Charcot advocated the anatomical-clinical method in neurology (Charcot, 1879), contributing to the description or delineation of several syndromes and diseases, such as multiple sclerosis and Parkinson's disease (Charcot, 1868; Charcot and Vulpian, 1862a) and described eponymous conditions such as amyotrophic lateral sclerosis- also known as Charcot's disease- (Charcot, 1874; Charcot and Joffroy, 1869; Charcot and Marie, 1885) and Charcot-Marie-Tooth disease (Charcot and Marie, 1886). He later mostly focused on hysteria and hypnosis (Bogousslavsky et al., 2009; Faber, 1997; Goetz, 2007; Lhermitte, 1950) and developed organicist conceptions that the School of Nancy strongly opposed.

While holding his chair at the Salpêtrière, Charcot had the meritone, -and not the least, of his merits was to- of surrounding himself with major collaborators such as Alix Joffroy (18441908), Albert Gombault (1844-1904), Paul Richer (1844-1933) (Charcot and Richer, 1900), Georges Debove (1845-1920), Fulgence Raymond (1844-1910), Albert Pitres (1848-1928), ÉEdouard Brissaud (1852-1909) (Charcot et al,., 1891) Gilbert Ballet (1853-1916), Pierre Marie (1853-1940), Joseph Babinski (1857-1932), Georges Gilles de la Tourette (1857-1904), Alexandre Achille Souques (1860-1944) and many others. IIt is difficult, today, today to take the full measure of what the glory of the neurologist of the Salpêtrière hospital was like at the end of the XIXth Century. His reputation on both national and international levels came from the lectures he gave on Tuesdays (the less technical and more for theaimed at general public) (Charcot et al., 1887; Charcot and Bourneville, 1872, 1876), on the side ofas well as from his private Friday lectures. Eexclusively for scientists,: they attracted the tout Paris (Parisian smart set). The famous painting from André Brouillet (1857-1914) Une leçon clinique à la Salpêtrière (A clinical Llecture at the Salpêtrière) displayed at the salon of 1887 immortalized them (Figure 5). On this painting we can see the "master" Charcot examining the his famous hysterical patient Blanche Witmann (1859-1913), physically held up by his assistant Babinski. Around them are most of Charcot's students and some Parisian important figures. In 1881 Charcot was celebrated as a hero at the Medical congress of London. Sigmund Freud (18591913) spent a few months in the service unit of Charcot (from October 1885 to February 1886) and then kept friendly relations with him. He translated his lectures into German and preserved kept a reproduction of Brouillet's painting in his living room during for all his lifetime.

\section{Alfred VULPIAN (1826-1887)}

Vulpian (Figure 6) began his medical studies under the influence of Pierre Flourens (Breathnach, 1987; Cousin, 2002; Dellon and Dellon, 1993; Pearce, 2002b; Vulpian, 1880). His MD thesis dealt withwas about the origin of cranial nerves, from the 3rd to the 10th (Vulpian, 1853). He became successively interne des hôpitaux de Paris and associate 
professor. In 1862, he was named he along withand his friend Charcot, were named Head of two different departments at the Salpêtrière hospital. Vulpian was named full professor of the chair of pathology in 1866, succeeding Jean Cruveilhier (1791-1874). In 1872 he let the chair of pathology to Charcot and took hold of the chair of experimental and comparative pathology (Vulpian and Brémond, 1866). His work, although slightly overshadowed by the glory of his student Dejerine and that of Charcot (Bogousslavsky et al., 2011), is extensive in the field of clinical anatomy and physiology of nervous diseases.

In 1859 Vulpian was the first to have the idea of growing animal tissues by isolating tadpole tail fragments, thus obtaining the survival of cells without any proliferation. Vulpian described the conjugate deviation of the head and eyes in apoplectic ictus in 1864, and the clinical spectrum of multiple sclerosis in 1866 (Rascol and Clanet, 1982; Vulpian, 1866) with Charcot, by distinguishing it from other forms of tremor such as paralysis agitans.. They also studied this latter condition and (which they named it Parkinson's disease) (Charcot and Vulpian, 1862c), as well as amyotrophic lateral sclerosis. Vulpian was the first to demonstrate that tabes dorsalis - contrary to the general opinion of that time - does not primarily affect the posterior columns of the cord (Charcot and Vulpian, 1862b). He was a refined clinician and coined, for example, the term syncinésie (synkinesia). He was elected to the Académie des Sciences and was the dean of the Paris Medical Faculty from 1875 untill 1881.

\section{Désiré-Magloire BOURNEVILLE (1840-1909)}

Bourneville (Figure 7) was born in Normandy, in north-western France and studied medicine in Paris (Anonymous, 2005; Poirier and Chrétien, 2000a; Poiret and Signoret, 1991a, 1991b; Poisson, 2008). He became intern/ resident of Charcot in 1868 and, from then on, had a huge impact on him, in particular for his works on hysteria (Bourneville, 1876; Bourneville and Voulet, 1972). He was appointed médecin-aliéniste des hôpitaux de Paris and developed new methods for the management of the mentally retarded, at the Bicêtre hospital (Bourneville, 1905a, 1905b; Reyre, 1989). His name remains associated with the discovery of the sclérose tubéreuse de Bourneville (Bourneville's tuberous sclerosis) (Bourneville, 1880a, 1880b) and the description of the myxoedème congénital (congenital myxedema). Bourneville was a republican, a freethinker, a freemason, an anticlerical (Brais, 1993) and was very involved in the major political struggles of the French Third Republic. He was successively conseiller municipal (municipal councillor) of Paris, député du département de la Seine (deputy of the Seine County) and belonged to the extreme left-wing of the parti radical (French radical party). Bourneville founded the municipal nurse schools (Bourneville, 1881; Collière, 1999) and vigorously fought for the laicisation secularisation of hospitals and for the promotion of cremation. He founded the journals Archives de Neurologie and Le Progrès Médical.

Paul RICHER (1849-1933)

Intern resident of Charcot in 1878, Richer (Figure 8) was both a physician and an artist. In 1888 and under the direction of Charcot, he founded the Nouvelle Iconographie de la Salpêtrière with Georges Gilles de la Tourette (1857-1904) and Albert Londe (1858-1917), which replaced the previous Iconographie Photographique de la Salpêtrière. The main interest of this scientific journal lay in the numerous photographs, coloured lithographs and drawings by Paul Richer which illustrated the articles on the neurological cases observed at the Salpêtrière hospital (Charcot and Richer, 1888, 1900; Richer, 1892; Richer and Meige, 1895). Richer published two brillantly illustrated books in collaboration with Charcot entitled : Les Démoniaques dans l'art (Demoniacs in art, 1887) (Charcot and Richer, 1887) and Les Difformes et les malades dans l'art (The Deformed and the dDiseased in art, 1889) (Charcot and Richer, 1889). He was also a sculptor and described human postures at rest and in motion (Richer, 1890). and hi His works include Premier Artiste (First Artist, 1890), Le Bûcheron de 
la forêt de La Londe (Lumberjack of the La Londe woods, 1899), Le Monument de Pasteur (A new Monument to Pasteur, 1903) and Tres In Una (Three in One, 1913), among others. Richer was a laureate of Institut de France, member of the Académie de Médecine (1898) and the holder of the chair of artistic anatomy of the École des Beaux-Arts (Paris Fine Arts School) (1903) (Richer, 1920a, 1920b) where Henry Meige (1866-1940) succeeded him. He was also the president of the Société française d'Histoire de la Médecine (French Society for the History of Medicine) (1907-1908).

\section{Henri PARINAUD (1844-1905)}

Parinaud (Figure 9) was born in Bellac (Haute-Vienne French département/ County in the center ofr France) and began his medical studies in Limoges (Ouvrier, 1993). He then studied in Paris, where he was successively externe and interne des hôpitaux de Paris (extern/ non residential student and intern/ resident of the hospitals of Paris), and served in the Red Cross ambulance corps during the Franco-Prussian war in 1870. Parinaud defended his MD thesis on optic neuritis in pediatric acute meningitis (Parinaud, 1877a) and Charcot handed him the direction of the service of ophtalmology thatwhich was belonged to his chair of the diseases of the nervous system. Parinaud published numerous works, notably on optic neuritis and strabismus (Parinaud, 1879a, 1879b, 1893). His name remains associated with upgaze paralysis (Parinaud's syndrome, which is caused by lesions of the mesencephalic area) (Parinaud, 1877b, 1886), to with the Parinaud's oculoglandular syndrome he described in 1889 (and that has subsequently been associated with the cat-scratch disease) (Parinaud, 1889), as well as to with the optometric scale (Parinaud scale) for the assesssment of visual acuity (Parinaud, 1888), which is still in use today. Parinaud is considered as one of the pionneers of French ophthalmology and particularly neuro-ophthalmology (Parinaud, 1898).

Albert PITRES (1848-1928)

Pitres (Figure 10) was born in Bordeaux and received his medical training in Paris, where he became resident of Charcot and Dejerine, and attended at ÉEtienne Jules Marey's (18301904) and Ranvier's respective laboratories. In 1877 he defended his MD thesis presided over by Charcot and entitled :entitled: Recherches sur les lésions du centre ovale des hémisphères cérébraux étudiées au point de vue des localisations cérébrales (Researches on the Llesions of the Ccerebral Hhemispheres Ooval Ccentres with Pparticular Ffocus on Ccerebral Llocalizations) (Pitres, 1877) and was admitted to the agrégation (French civil service competitive examination for positions in the public education system, either in secondary or higher education) in 1878 . He studied the different brain areas with Charcot, who was very much influenced by the British neuroscientist David Ferrier (1843-1928). He defended the doctrine of the "localizationism" and supported the idea of autonomous centres with specific functions (Charcot and Pitres, 1877, 1878a, 1878b, 1883, 1895). Albert Pitres witnessed the beginning of hypnosis during the lectures of Charcot in 1877-1878. Pitres then returned to Bordeaux where he became a professor of anatomy and histology in 1880 and then of internal medicine the next year. In 1884 he was the first to describe a clinical case of pure agraphia, and showed that an acquired motor ability could also be localized (Pitres, 1884a; Lorch and Barrière, 2003). Pitres also contributed to the study of aphasia and described amnesic aphasia (Pearce, 2005; Pitres, 1894, 1895, 1898). He continued his works on hysteria by following the ideas of Charcot's ideas. His book Les Lleçons cliniques sur l'hystérie et l'hypnotisme (Clinical 1Lectures on Hhysteria and Hhypnotism) was published in 1891 (Pitres, 1891). However, he gave up this study topic after Charcot's death and resumed his works on memory and peripheral nerves. He was the dean of the Faculty of Medicine of Bordeaux. His name is associated with two signs: the signe du sou de Pitres (Pitres' coin sign) in pneumothorax and 
the signe de Pitres (Pitres' sign) in tabes dorsalis (hypoesthesia or anesthesia of the scrotum) (Pitres, 1884b).

\section{Jules Joseph DEJERINE (1849-1917)}

Dejerine (Figure 110) was a student of Vulpian but not of Charcot (Anonymous, 1969; Basseti and Jagella, 2006). He was a médecin des hôpitaux de Paris, an associate professor and headed a department at the Bicêtre hospital (1887), before moving to the Salpêtrière hospital in 1895. He then became pProfessor of Medical history (1901) then of Medical Pathology (1907), he succeeded Fulgence Raymond (1844-1910) at the chair of the diseases of the nervous system in 1911. In 1888, Dejerine married Augusta Klumpke (see next biography)., an American medical student and the first woman to pass the competitive examination to become an intern/ resident of the Paris hospitals in 1886. She would remain an effective collaborator to her husband. Among Dejerine's numerous publications, the most famous are the Landouzy-Dejerine syndrome or facio-scapulo-humeral muscular dystrophy (1885) (Landouzy and Dejerine, 1885), the Dejerine-Sottas hypertrophic neuropathy (1893) (Dejerine and Sottas, 1893), and in collaboration with André Thomas (1900) the sporadic form of the olivo-ponto-cerebellar atrophy (OPCA) (Dejerine and Thomas, 1900) and most importantly the Dejerine-Roussy syndrome caused by a lesion in the posterior thalamus (1906) (Dejerine and Roussy, 1906; Pearce, 1988). Dejerine did also important contributions on reading and writing, and particularly on word blindness (Bub et al., 1993; Dejerine, 1892; Henderson, 1984).

Three of his books remain especially important today: the Traité des maladies de la moelle épinière (Treatise on sSpinal Ccord Ddiseases) in collaboration with André Thomas (Dejerine and Thomas, 1902) and the two masterpieces that are Anatomie des Centres Nerveux (Anatomy of the Nnervous Ccenteres, 1895-1901) (Dejerine and Dejerine-Klumpke, 1895), a monumental piece of work with a rich iconography established fromof large anatomical sections and for which the participation of Mrs Dejerine-Klumpke was of critical importance, and Sémiologie des affections du système nerveux (Semiology of the Ddiseases of the Nnervous Ssystem, 1914) (Dejerine, 1914), which is today considered as one of the greatest classics of the francophone French neurological literature. Although the major part of his work deals withis about organic neurology, Dejerine turned to a new field in the later stages of his career. Like many eminent neurologists of that time he became interested in psychology, functional disorders and hysteria. He published Les mManifestations fonctionnelles des psychonévroses, leur traitement par la psychothérapie (The Ppsychoneuroses and Ttheir tTreatment by Ppsychotherapy) with E. Gauckler in 1911 (Dejerine and Gauckler, 1911).

\section{Augusta DEJERINE-KLUMPKE (1859-1927)}

Augusta Klumpke, Dejerine's wife (Figure 110) was born in San-Francisco and studied at the Faculty of Medicine of Paris (Bauer, 1974; Bogousslavsy, 2005; Ellis, 2011; Satran, 1974; Schurch and Dollfus, 1998; Yildirim and Sarikcioglu, 2008). After a long struggle against the unwillingness of the the medical body profession and the hospital administration unwillingness, she obtained the authorization to take the hospital competitive examination. She was appointed extern/ non-residential student in 1882 and became the first woman female resident of the Paris hospitals in 1886. As an extern/ non residential student she published -on her own - the princeps article on the lower brachial plexus paralysis in Revue de médecine, 
today known as the Klumpke's paralysis, or Dejerine-Klumpke syndrome (Anonymous, 1999; Dejerine-Klumpke, 1908; Klumpke, 1885; Ulgen et al., 2008). As When she was an intern/ resident of Professor Alfred Hardy (1811-1893) at the Charité hospital, her chief resident was Jules Dejerine who became her husband in 1888. She defended her MD thesis on Les Polynévrites en général, les paralysies et les atrophies saturnines en particulier (About Ppolyneuritis in Ggeneral and Ssaturnian Ppalsies and Aatrophies in Pparticular) in 1889 (Dejerine-Klumpke, 1889). Mrs Dejerine-Klumpke did important works on neuroanatomy (Dejerine-Klumpke and Jumentié, 1910; Lecours and Caplan, 1984; Schoja and Tubbs, 2007) and took an active part in the writing of Anatomie des centres nerveux ("Anatomy of the Nnervous Ccenteres"), co-signed with her husband (Dejerine and Dejerine-Klumpke, 1895). She was the president of the Sociéte Société de Neurologie de Paris in 1914 and 1915. During World War I she headed a service consisting of 300 beds unit, ofcaring for wounded patients at the Salpêtrière hospital. She became Officier de la Légion d'Honneur (Officer of the Legion of Honor) in 1921.

\section{Édouard BRISSAUD (1852-1909)}

Brissaud (Figure 121) was successively resident of Paul Broca (1824-1880), Ernest-Charles Lasègue (1816-1883) and Charcot (Freeman, 1953; Poirier, 2010, 2011; Tatu, 2011). He became médecin des hôpitaux de Paris, agrégé, professor of the history of medicine (1899) then of medical pathology (1900). He dedicated many of his works among others to infantilism (and described its thyroid form) (Brissaud, 1897) and, gigantism (Brissaud and Meige, 1895a), asthma (Brissaud, 1896), Llittle disease (Brissaud, 1894), intonation in aphasia (Brissaud, 1901), herpes zoster, spinal metamerism and, tabetic arthropathy. Brissaud did two famous lectures on Parkinson's disease and on, tics and spasms (Brissaud, 1895a, 1895b). Brissaud He notably studied hemifacial spasm and torticollis, with photographic illustrations (Brissaud, 1895b; Colosimo and Berardelli, 2010). He proposed the term torticolis mental ("mental torticollis") on the basis of the description of an important feature (Brissaud, 1895b) hemifacial spasm and mental torticollis, the later of which presenting an important sign subsequently denominated as geste antagoniste ("antagonistic movement") by his pupils Henry Meige (1866-1940) and Eugène Feindel (1862-1930). He demonstrated the automatic-voluntary dissociation between the voluntary expression and facial expression in pseudobulbar palsy. In 1896, a few months after Roentgen's dis-covery of X-rays, Brissaud and Albert Londe (1858-1917) used this new method to localize set an intracranial projectile and on the radiographlocalize its image, with awhose fixture time was then of one hour and a half! Brissaud was the project initiator of Charcot and Bouchard famous Traité de médecine (Treatise of Medicine) (Charcot et al., 1891) and of Pratique Médico-Chirurgicale (MedicalSurgical Practice) published in collaboration with Paul Reclus (1847-1914) and Adolphe Pinard (1844-1934) (Brissaud et al., 1907). In 1893, he published an atlas on human brain anatomy (Brissaud, 1893). The same year, hWith Pierre Marie he founded the Revue Neurologique journal with Pierre Marie, which was supported by Charcot who published its very first article. After the death of Charcot in 1893, Brissaud replaced him at his Chair during for one year and published his Leçons sur les maladies du système nerveux (Lectures on the Ddiseases of the Nnervous Ssystem) (Brissaud and Meige, 1895b). Brissaud was one of the founding members of the Société de Neurologie de Paris (1899). 
Pierre Marie (Figure 132) was appointed interne des hôpitaux de Paris in 1878 and was a brilliant student of Charcot (Anonymous, 1983; Cohen, 1953; Goetz, 2003; Pearce, 2004a, 2004b; Poirier and Chrétien, 2000). At the end of his residency, he defended his M.D. thesis on Graves's disease (Marie, 1883) and became chief resident under the direction of Charcot. Together they described progressive muscular atrophy, later known as Charcot-Marie-Tooth disease (Charcot and Marie, 1886). He was associate professor and head of a department at the Bicêtre hospital and then at the Salpêtrière hospital, in 1895 and 1911 respectively. He was also was a professor of pathology in 1907 and a member of the Académie Nationale de Médecine. He described acromegaly (Pierre Marie disease) (Marie, 1886), cerebellar tonsil herniation (Simonetti et al., 1997) and hereditary cerebellar ataxia (Marie, 1893). He contributed to the study of bone and joint pathology (Ryckewaert and Naveau, 1984), and described hypertrophic pulmonary osteo-arthropathy (Marie, 1890),, hereditary cerebellar ataxia, hereditary cleidocranial dysostosis (Marie and Santon, 1898) and rhizomelic spondylosis (Benoist, 1995; Marie, 1898). His work on aphasia (Marie, 1906) was opposed to that of Paul Broca and Karl Wernicke (1848-1905), which resulted in famous and intense debates with Dejerine in 1908 (Brais, 1992; Roch-Lecours, 1999). Along wWith Édouard Brissaud, he founded the journal Revue de Neurologie in 1893, and the Société de Neurologie de Paris in 1899, of which he was the first General Secretary. He published various works dedicated to the neurological sequels of due to World War I, in collaboration with Charles Foix (1882-1927) and Henry Meige (1866-1940), among others (Marie and Foix, 1917). At the age of 64, he replaced Dejerine at the chair of the diseases of the nervous system, which he held for six years, from 1917 to his retirement in 1923.

\section{Georges ÉEdouard Brutus GILLES DE LA TOURETTE (1857-1904)}

Gilles de la Tourette (Figure 143) was intern/ resident (1884) then chief resident (1887-1889) of Charcot, médecin des hôpitaux de Paris (1893) and agrégé of medicine and forensic medicine (1895) (Goetz et al., 2001; Krämer and Daniels, 2004; Lees, 1986; Rickards and Cavanna, 2009; Walusinski and Bogousslavsky, 2011; Walusinski and Duncan, 2010). He is mostly famous for the maladie des tics (tic disorder) he described in 1885 and that which is named after him (Gilles de la Tourette, 1885, 1899; Goetz and Klawans, 1982; Lajonchère, 1996; Stevens, 1971). He also worked on hysteria and hypnotism (Bogousslavsky et al., 2009) and published two works on hypnotism and hysteriathis topic : L'Hypnotisme et les états analogues au point de vue médico-légal (Hypnotism and Aanalogous Sstates Ffrom the Mmedico-Llegal Ppoint of Vview, 1887) (Gilles de la Tourette, 1887) and Traité clinique et thérapeutique de l'hystérie d'après l'enseignement de la Salpêtrière (Clinical and Ttherapeutical Ttreatise on Hhysteria Bbased on the Salpêtrière Llectures 1891) (Gilles de la Tourette, 1891). Other medical publications are a treatise on the diseases of the nervous system, a study on gait and early description of restless legs syndrome (Gilles de la Tourette, 1886, 1898 ; Konofal et al., 2009). He also wrote a lot,was also a prolific writer, and notably produced numerous works on the Poitou Province in the centre of France and a biography of Théophraste Renaudot (1586-1653), a physician native from Loudun (as well aswas Gilles de la Tourette) and the founder of the very first French journal in 1631, La Gazette. Gilles de la Tourette suffered from a general paralysis caused by a tertiary syphilis and his mental condition gradually worsened. He died at the age of 47 in the psychiatric hospital of Lausanne where he had been confined.

Joseph BABINSKI (1857-1932) 
Babinski (Figure 145) was born in Paris to Polish parents who had fled Varsaw (Ambrosius and Michalak, 2009; Bayley, 1961; Gasceki and Kwieciński, 1995; Moreau, 1958; Philippon and Poirier, 2009; Poirier, 2007, 2008; Skalski, 2007). He studied medicine in the French capital, where he became resident of Vulpian and of Victor Cornil, and was chief resident of Charcot (1885-1887) (Massie, 2004). Babinski was appointed médecin des hôpitaux de Paris in 1890, but failed the agrégation in 1892, because of some quarrel between Charcot and the president of the jury, Charles Bouchard (1837-1915). As a consequence Babinski would never be a professor. He remained head of the Neurologya medical department at the Pitié hospital during for his entire career, first in the old Pitié hospital until 1912 and then in the new Pitié hospital which was opened the same year, in a contiguous area ofwith the Salpêtrière hospital. Babinski did considerable contributions to the study of diseases of the nervous system (Babinski, 1913, 1934). He was above all a semiologist and his constant aim was to discover characteristic signs that allowed allowing to make the distinction between organic pathology and functional, hysterical disorders. During a presentation of 28 lines at the Sociéte de Biologie (French Society of Biology) Iin 1896, he showed during a presentation of 28 lines at the Sociéte de Biologie (French Society of Biology) that stimulation of the sole of the foot caused an extension of the great toe in patients with a lesion of the pyramidal tract whereas it resulted causedin a flexion in normal subjects (Babinski, 1896). This inversion of the cutaneous plantar reflex sign would very quickly be called Babinski sign (Goetz, 2002; Lance, 2002). After the death of Charcot, Babinski reconsidered the position of his master on hysteria and suggested to rename it pithiatisme (pithiatism) in order to show that it is a disorder caused by suggestion and that can be treated by persuasion (Allilaire, 2007; Babinski et al., 1918). Thanks to the long observation of his patient Henri Mouninou, Babinski refined the cerebellar semiology and decribed asynergia (i.e cerebellar ataxia), hypermetria and adiadochokinesia (Babinski, 1899, 1902a, 1902b, 1902c, 1909, 1925; Babinski and Tournay, 1913). Babinski finally was at the origin of the birth of French neurosurgery by encouraging his students Clovis Vincent (1879-1947) and Thierry de Martel (1876-1940) to become accomplished neurosurgeons (Babinski et al., 1912). Babinski lived all his life with his older brother Henri Babinski (1855-1931), who was an engineer but was mostly famous as a distinguished cook. As "Ali Bab", he wrote a classic cookbook entitled Gastronomie Pratique: études culinaires (Practical gGastronomy: Cculinary sStudies) (Babinski, 1907). Joseph Babinski suffered from Parkinson's disease at the end of his life and died one year only after his brother.

\section{André THOMAS (1867-1963)}

André Thomas (Figure 165) made spent his entire medical career in Paris (De Ajuriaguerra, 1955; Duckett, 2000; Hécaen and Bonduelle, 1967; Polonovski, 1999; Sigwald, 1967; Soriano, 1967). He was first an intern/ resident at the Bicêtre hospital, where Dejerine was his mentor, then worked at the Salpêtrière and later at the Saint- Joseph Hospital. It is noteworthy that when he retired, he focused on the study of child neurology (Thomas and Saint Anne Dargassies, 1952; Thomas and De Ajuriaguerra, 1949). Although André Thomas did numerous publications in neurology, as for example on spinal cord with Dejerine (Dejerine and Thomas, 1902), Hhis most important research was on the study of the cerebellum. In parallel with Babinski in France and Gordon Morgan Holmes (1876-1965) in Great Britain, he was one of the main contributors to the study of cerebellar disorders at the turn of the XIXth and XXth centuries (Thomas, 1897, 1905; Thomas et al., 1914; Thomas and Jumentié, 1909). While Babinski reported asynergia, hypermetria and adiadochokinesia, André Thomas added dysmetria, dyschronometria (Thomas, 1937) and passivité (i.e. hypotonia) with the pendular reflexes. Gordon Holmes further characterized hypotonia (Stewart-Holmes maneuver), delayed initiation or arrest of movement and action tremor, and identified rubral 
tremor (now called Holmes tremor). In 1900 Dejerine and Thomas described a new syndrome:, olivopontocerebellar atrophy (OPCA) (Dejerine and Thomas, 1900). This degenerative disease occurreds sporadically at middle or elderly age. The main pathological feature was is a severe atrophy of the cerebellum, inferior olives and protuberancepons. OPCA was subsequently recognized by others with in some cases, an akinetic rigid syndrome. In the 1960s Shy-Drager and striatonigral degeneration syndromes were described by others. Important histopathological data in the late 1980s showed that these two entities and OPCA shared common oligodendroglial inclusions with different anatomical distributions. These three syndromes were later coalesced under the term multiple system atrophy (MSA).

Georges MARINESCO (1864-1938)

Georges Marinesco (Figure 176), also known as Gheorghe Marinescu, was born in Romania and received most of his medical education at the Brâncoveanu (Brancovan) Hospital and worked at the laboratory of histology and bacteriology of Victor Babes (1854-1926) (Buda et al., 2009; Chudley, 2003; Petresco, 1964). Marinesco later came to Paris to receive further education in neurology with Charcot at the Salpêtrière hospital, where he was in close contact with Pierre Marie, Babinski and Raymond. He also worked in Germany with Karl Weigert (1845-1904) in Frankfurt and Emil Du Bois Reymond (1818-1896) in Berlin. Back in Romania he holded held the very first chair of neurology in Bucharest and founded the Romanian School of Neurology. He published an atlas on of the pathological histology of the nervous system with Victor Babes and Paul Oskar Blocq (1860-1896) (Blocq et al., 1892). Marinesco's contribution to science is outstanding. He had indeed the ingenuity to put to use new methods in practice, as soon as they were available, especially roentgen rays, film camera and Nissl method. The book he published on this latter topic dealt with the study of normal nerve cells and reparative processes in neurofibrils in the degenerated cells following nerve section (Marinesco, 1905a, 1905b, 1918, 1920). With Blocq, he reported a peculiar case of parkinsonian tremor related to tuberculosis abcesses of the mesencephalon (Blocq and Marinesco, 1893), and discovered the senile plaques (Marinesco, 1911, 1928). . Marinesco was the first to carry out hypophysectomy in animals in order to demonstrate that they could live for a few weeks without pituitary gland (Marinesco, 1892). He also studied a new form of familial spastic paraplegia with extrapyramidal motor symptoms, clinical-anatomical aspects of the thalamic syndrome, juvenile form of familial amaurotic idiocy and degenerative changes in of the spinal cord following amputations (Marinesco-Sjögren syndrome) (Marinesco et al., 1925). He maintained close academic relationships with his colleagues in Paris. In 1909 he published a voluminous work on the nerve cell entitled La cCellule nerveuse (The Nnerve Ccell) that was later overshadowed by Ramón y Cajal's works (Marinesco, 1909).

\section{Achille Alexandre SOUQUES (1860-1944)}

Achille Alexandre Souques (Figure 187) studied medicine in Paris, went toworked at the Salpêtrière Hospital, became Charcot's last interne (resident), then Brissaud's chef de clinique (assistant professor) (Alajouanine, 1945, 1953; Broussolle et al., 2010; Société Française de Neurologie, 1945). In 1898 he became a hospital consultant and worked successively at the Charité, the Hôtel-Dieu, the Ivry and the Bicêtre hospital. He returned to the Salpêtrière Hospital in 1917 where he was appointed Professor of Neurology. With Pierre Marie, Joseph Babinski and others, Souques founded the Paris Neurological Society in 1899, with Pierre Marie, Joseph Babinski and others. He was elected at the Académie Nationale de Médecine in 1918 and retired in 1925.

Souques described several important neurological signs. One sign bears his name: Signe des cils de Souques (i.e. Souques' eyelashes sign) in formes frustes of facial paralysis. In this 
case, the involvement of the upper facial nerve territory can be detected when the patient is asked to strongly close his eyes strongly: the eyelashes are less covered by the eyelids and thus appear longer compared to those of the non-paralysed side. Souques also studied speech and language and described palilalia in 1908 (Souques, 1908). PI this syndrome, patients affected by this syndrome cannot help repeating the same word or sentence. This speech disorder is frequently seen in stroke patients, especially in case the course of pseudobulbar palsy and in parkinsonian syndromes. In 1915, Souques coined the term camptocormia with Mrs Rosanoff-Saloff to describe the abnormal curve of the trunk in injured trench warfare soldiers (Souques and Rosanoff-Saloff, 1915). Some soldiers had a camptocormia due to the stress of the anticipation of the battle, whereas others were afraid to suffer again from a previous spinal cord injury. Nowadays, camptocormia is considered not only as a psychogenic disorder, but is also described as part of Parkinson's disease, dystonia, myopathic processes and amyotrophic lateral sclerosis (Djaldetti et al., 1999; Skidmore et al., 2007)..

Souques' work on parkinsonian syndromes is remarkable. During an International Congress in Paris in 1921, he updated the scientific knowledge on Parkinson's disease and postencephalitic parkinsonian syndromes with In his famous 1921 exhaustive review during an International Congress in Paris,(Souques, 1921) he updated the scientific knowledge on Parkinson's disease and postencephalitic parkinsonian syndromes. Souques considered that post-encephalitic parkinsonism was indistinguishable from idiopathic Parkinson's disease and added two original contributions: first, abolition of automatic and associated movements, as the loss of the automatic swinging of the arms while walking; second, kinésie paradoxale (paradoxical kinesis). Souques used this term to refer to patients who generally could not move and were suddenly able to walk, or even to run. This phenomenon could can also be seen in speech.

After his retirement, Souques did an important contribution to the study of neurology in the ancient Greece (Souques, 1936).

Georges GUILLAIN (1876-1961)

Guillain (Figure 198) succeeded his teacher Pierre Marie at the chair of Charcot, which he held from 1923 to 1947 (Alajouanine, 1962; Bonduelle, 1977, 1997; Mollaret, 1961). He was a mMember of the Académie Nationale de médecine and of the Académie des sciences, and he was Commandeur de la Légion d'Honneur (Commander of the Legion of Honor). With P. Léchelle, physician of Paris hospitals, he discovered the colloidal benzoic reaction (Guillain et al., 1922, 1926) and participated in the description of numerous eponymous syndromes. The most famous is the syndrome of acute polyradiculoneuritis or Guillain-Barré syndrome (also known as Guillain-Barré-Strohl) (Asbury, 1990; Guillain, 1938; Guillain et al., 1916). Guillain also wrote many articles on various affections of the nervous system such as myoclonus, notably palatal myoclonus with the description of the Guillain-Mollaret-Bertrand myoclonus triangle (1933) (Guillain and Mollaret, 1931, 1936; Guillain et al., 1933) and heredodegenerative diseases of the spinal cord (Cestan and Guillain, 1900). He published several books such as the Travaux neurologiques de guerre (Wartime nNeurological Wworks) with Jean Alexandre Barré (1880-1967) (Guillain and Barré, 1920), Ll'Anatomie topographique du système nerveux central (Topographic Aanatomy of the Ccentral Nnervous Ssystem) with Ivan Bertrand (1893-1965) (Guillain and Bertrand, 1926). He also wrote aA monograph on the Salpêtrière hospital with Mathieu (Guillain and Mathieu, 1925), and a biography of Charcot (Guillain, 1955). His student Théophile Alajouanine (1890-1980) succeeded him at Charcot's chair of the diseases of the nervous system in 1947. 
Charles FOIX (1882-1927)

Charles Foix (Figure 2019) did his medical internship in Paris (1906) where he studiedalong with Pierre Marie and headed his laboratory at the Salpêtrière hospital (Breathnach, 1982; Caplan, 1990, 2010; Hillemand, 1976). Foix served during World War I in the neurological center of Salonica in Greece and was successively médecin des hôpitaux de Paris and associate professor in 1919 and 1923, respectively. He succeeded Clovis Vincent at the Ivry hospice (1924), where his reputation attracted many foreign visitors. His scientific contribution is considerable, both in terms of quantity and quality. One may especially mention his works on the anatomical lesions of Parkinson's disease (Foix, 1921), Lewy bodies and on palatal myoclonus (Foix and Hillemand, 1924). He also made an accurate description of the brain arteries and their territories (Foix and Hillemand, 1925a, 1925b; Foix and Masson, 1923; Tatu et al., 2005) and of the vascular syndromes depending on their pathology, with several original descriptions (Caplan, 1990; Foix, 1911; Foix et al., 1925; Foix and Hillemand, 1925c, 1925d). Charles FoixHis other important publications with his contemporary colleagues are: on a fine anatomy of the mesencephalon sub-optic area (with Jean Nicolesco, 1895-1957)(Foix and Nicolesco, 1925), a cranial-cerebral topography (with Pierre Marie and Ivan Bertrand), several studies on cerebellar syndromes (with Pierre Marie and Thiers)and, late cerebellar atrophy with cortical predominance (with Pierre Marie and Alajouanine)(Marie et al., 1922),. Among other contributions are his work on aphasia (with Pierre Marie) (Marie and Foix, 1917), necrotic myelopathy (Ferrel et al., 2009; Foix and Alajouanine, 1926) and anterior opercular syndrome (known as Foix-Chavany-Marie syndrome) (Foix et al., 1926). Charles Foix was also an author of prose and poetry.

\section{Acknowledgements}

The authors would like to thank for their tremendous help Chloé Loiraud, Yann Bregeras, Sandrine Jamen and Jessica Moreau from Bibliothèque Médicale, Hôpital Neurologique Pierre Wertheimer, Lyon, France, Chantal Barbara, Marjorie Lorch (ISHN), the École des Neurosciences de Paris, the Club d'Histoire des Neurosciences from the Société des Neurosciences and the BIU Santé (Bibliothèque Inter Universitaire de Santé de Paris) and the Académie Nationale de Médecine and Académie des Sciences for the reproduction of photographs.

\section{Conflicts of interest : none}

\section{References}

1. Alajouanine T. Nécrologie. Achille Souques (1860-1944). Presse Méed 1945; 47: 647-648.

2. Alajouanine T. Achille Alexandre Souques (1860-1944). In: Webb Haymaker, editor. The Founders of Neurology. Springfield, Illinois USA: Charles Thomas Publisher; 1953. p. 385-388.

3. Alajouanine T. Georges Guillain (1876-1961). Bull Acad Natl Méed 1962;146:18-26.

4. Allilaire J. Babinski et 1'hystéerie. Bull Acad Natl Méed 2007;191:1329-1339; discussion 1340-1341.

5. Ambrosius W, Michalak S. Joseph Babinski -- French neurologist of Polish descent. Eur J Neurol 2009; 16:e44.

6. Anonymous. Joseph Jules Dejerine (1849-1917). JAMA 1969;207:359-360.

7. Anonymous. Classics in neurology: Pierre Marie. Leçons sur les maladies de la moeëlle. 1892. Neurology 1983;33:1066. 
8. Anonymous. Klumpke A. Klumpke's paralysis. 1885. Clin Orthop Relat Res 1999;(368):3-4.

9. Anonymous. L'œuvre méedico-pédagogique du docteur Désiré Bourneville. Rev Soc Fr Hist Hôop 2005;(120):30.

10. Asbury AK. Guillain-Barré syndrome: historical aspects. Ann Neurol 1990;27 Suppl:S2-6.

11. Babinski H. Gastronomie pratique. Paris: Flammarion; 1907.

12. Babinski J. Sur le réflexe cutané plantaire dans certaines affections organiques du système nerveux central. C R Séances Soc Biol Fil 1896;48:207-208.

13. Babinski J. De l'asynergie cérébelleuse. Rev Neurol (Paris) 1899;7:806-816.

14. Babinski J. Asynergie et ataxie cérébelleuse. Rev Neurol (Paris) 1902;10:685-686.

15. Babinski J. De l'équilibre volitionnel statique et de l'équilibre volitionnel cinétique (dissociation de ces deux modes de l'équilibre volitionnel, asynergie et catalepsie). Rev Neurol (Paris) 1902;10:470-474.

16. Babinski J. Sur le rôle du cervelet dans les actes volitionnels nécessitant une succession rapide de mouvements (diadococinésie). Rev Neurol (Paris) 1902;10:1013-1015.

17. Babinski J. Quelques documents relatifs à l'histoire des fonctions de l'appareil cérébelleux et de leurs perturbations. Rev Mens Méed Int Théerap 1909;2:114-129.

18. Babinski J. Exposé des travaux scientifiques du Dr J. Babinski. Paris: Masson; 1913.

19. Babinski J. Syndrome cérébelleux. Bull Acad Méed Paris 1925;93:422-424.

20. Babinski J. CEuvre scientifique. Paris: Masson ;1934.

20.21. Babinski J, Froment J, Rolleston J. Hysteria or pithiatism and reflex nervous disorders in the neurology of war. London: Univ. of London Press; 1918.

21.22. Babinski J, Lecène $P$, Bourlot. Tumeur méningée; Paraplégie crurale par compression de la moeëlle; Extraction de la tumeur, guérison. Rev Neurol (Paris) 1912;21:1-4.

22.Babinski J, Nageotte J. Hémiasynergie, latéropulsions et myosis bulbaires avec hémianesthésie et hémiplégie croisées. Rev Neurol (Paris) 1902;10:358-365.

23. Babinski J, Tournay A. Premier rapport; Symptômes des maladies du cervelet. Rev Neurol (Paris) 1913;26:306-322.

24. Bailey P. Joseph Babinski (1857-1932). The man and his works. World Neurol. 1961;2:134-140.

25. Bariéty M. Eloge Éloge d'Armand Trousseau (14 October 1801-23 June 1867). Bull Acad Natl Méed 1967;151:627-635.

26. Bassetti CL, Jagella EC. Joseph Jules Dejerine (1849-1917). J Neurol 2006;253:823-

824.

27. Bauer J. Letter: Augusta Dejerine-Klumpke. Ann Intern Med 1974;81:128.

28. Benoist M. Pierre Marie. Pioneer investigator in ankylosing spondylitis. Spine 1995;20:849-852.

29. Blocq P, Babes V, Marinesco G. Atlas der pathologischen Histologie des

Nervensystems. Berlin: Hirschwald; 1892.

30.Blocq P, Marinesco G. Sur les lésions et la pathogénie de l'épilepsie dite essentielle. Semaine Med 1892;12:445-466.

31.30. Blocq P, Marinesco G. Sur un cas de tremblement parkinsonien hémiplégique symptomatique d'une tumeur du pédoncule cérébral. Mem Soc Biol 1893;5:105-111.

32.Bogousslavsky J. Charcot and art: from a hobby to science. Eur Neurol 2004;51:78-83.

33.31. Bogousslavsky J. The Klumpke family-memories by Doctor Déjerine, born Augusta Klumpke. Eur Neurol 2005;53:113-120.

34.32. Bogousslavsky J, editor. Following Charcot : a forgotten history of neurology and psychiatry. Frontiers of Neurology and Neuroscience (volume 29). Basel: Karger; 2011. 
35.33. Bogousslavsky J, Walusinski O, Moulin T. Alfred Vulpian and Jean-Martin Charcot in each other's shadow? From Castor and Pollux at La Salpêtrière to neurology forever. Eur Neurol 2011;65:215-222.

36.34. Bogousslavsky J, Walusinski O, Veyrunes D. Crime, hysteria and belle époque hypnotism: the path traced by Jean-Martin Charcot and Georges Gilles de la Tourette. Eur Neurol 2009;62:193-199.

37.35. Bonduelle M. Georges Guillain (1876-1961). Rev Neurol (Paris) 1977;133:661-666.

38.36. Bonduelle M. Histoire de la médicine: Georges Guillain (1876-1961). Rev Neurol

(Paris) 1997;153:163-171.

39.37. Borg K. The man behind the syndrome: Guillaume Duchenne. J Hist Neurosci 1992;1:145-154.

40.Bourneville DM. Mémoire sur l'inégalité de poids entre les hémisphères cérébraux des épileptiques. Paris: Imp. Brière; 1861.

41.Bourneville DM. Études de thermométrie clinique dans l'hémorrhagie cérébrale et dans quelques autres maladies de l'encéphale. Thèse de Médecine : Paris ; 1870.

42.Bourneville DM. Études cliniques et thermométriques sur les maladies du système nerveux. Paris: A. Delahaye; 1872.

43.38. Bourneville DM. Recherches cliniques et thérapeutiques sur l'épilepsie et l'hystérie :

Compte rendu des observations recueillies à la Salpêtrière de 1872 à 1875. Paris: A.

Delahaye; 1876.

44.39. Bourneville DM. Encéphalite ou sclérose tubéreuse des circonvolutions

cérébrales. Arch Neurol. 1880;1:297.

45.40. Bourneville DM. Sclérose tubéreuse des circonvolutions cérébrales: idiotie et épilepsie hémiplégique. Arch Neurol 1880;1:81-91.

46.41. Bourneville DM. Laïcisation de l'Assistance publique. Paris: [s.n.]; 1881.

47.42. Bourneville DM. Les enfants anormaux au point de vue intellectuel et moral. Paris:

Aux Bureaux du Progrès Médical; 1905.

48.43. Bourneville DM. Traitement médico-pédagogique des différentes formes de l'idiotie.

Paris: Alcan; 1905.

49.44. Bourneville DM, Voulet P. De la contracture hystérique permanente. Paris: A.

Delahaye; 1872.

50.45. Brais B. The third left frontal convolution plays no role in language: Pierre Marie and the Paris debate on aphasia (1906-1908). Neurology 1992;42:690-695.

51.46. Brais B. Désiré Magloire Bourneville and French anticlericalism during the Third Republic. Clio Med 1993;23:107-139.

52.47. Breathnach CS. Biographical sketches no. 24 - Foix. Ir Med J 1982;75:445.

53.48. Breathnach CS. Biographical sketch. Vulpian. Ir Med J 1987;80:157.

54.Brissaud É. Des paralysies toxiques. Paris: Asselin et Houzeau; 1886.

55.49. Brissaud É. Anatomie du cerveau de l'homme : morphologie des hémisphères cérébraux, ou cerveau proprement dit. Paris: Masson; 1893.

56.50. Brissaud É. Maladie de Little et tabes spasmodique. Semaine Med. 1894;14:89.

57.51. Brissaud É. Vingt-troisième leçon, nature et pathogénie de la maladie de Parkinson.

In: Leçons sur les maladies nerveuses: la Salpêrière, 1893-1894. Paris: Masson; 1895. p. 488501.

58.52. Brissaud É. Vingt-quatrième leçon, tics et spasmes cloniques de la face. In: Leçons sur les maladies nerveuses: la Salpêrière, 1893-1894. Paris: Masson; 1895. p. 502-520.

59.53. Brissaud É. L'hygiène des asthmatiques. Paris: Masson; 1896.

60.54. Brissaud É. De l'infantilisme myxoedémateux. Nouvelle Iconographie de la Salpêtrière 1897; 10:240. 
61.55. Brissaud É. Aphasie d'articulation sans aphasie d'intonation. Rev Neurol (Paris) 1901;9:666-669.

62.Brissaud É, Londe PFL. Sur un cas d'hérédo-ataxie cérébelleuse. Paris: G. Masson; 1894. 63.56. Brissaud É, Meige H. Gigantisme et acromégalie. Paris: A. Coccoz; 1895.

64.57. Brissaud É, Meige H. Leçons sur les maladies nerveuses. 1, Salpêtrière 1893-1894. Paris: G. Masson; 1895.

65.58. Brissaud É, Pinard A, Reclus P. Pratique médico-chirurgicale : médecine et chirurgie générales et spéciales; obstétrique, puériculture, hygiène, médecine légale, accidents du travail, psychiatrie, chimie et bactériologie cliniques, etc. Paris: Masson; 1907.

59. Brody IA, Wilkins RH. Neurological Classics XIII. Duchenne's muscular dystrophy. Arch Neurol 1968;19:628-636.

66.60. Broussolle E, Loiraud C, Thobois S. Achille Alexander Souques (1860-1944). J Neurol 2010;257:1047-1048.

67.61. Bub DN, Arguin M, Lecours AR. Jules Dejerine and his interpretation of pure alexia. Brain Lang 1993;45:531-559. Anonymous. Joseph Jules Dejerine (1849-1917). JAMA 1969;207:359-360.

68.62. Buda O, Arsene D, Ceausu M, Dermengiu D, Curca GC. Georges Marinesco and the early research in neuropathology. Neurology 2009;72:88-91.

69.63. Caplan LR. Charles Foix, the first modern stroke neurologist. Stroke 1990;21:348-356.

70.64. Caplan LR. Charles Foix (1882-1927). J Neurol 2010;257:1941-1942.

71.65. Cestan R, Guillain G. La paraplégie spasmodique familiale et la sclérose en plaques familiale. Rev Med 1900;10:813-836.

72.66. Charcot JM. Histologie de la sclérose en plaques. Gaz Hop 1868;41:554-555;557$558 ; 566$.

73.67. Charcot JM. De la sclérose latérale amyotrophique. Prog Med 1874;2:325-7.

74.68. Charcot JM. Anatomie pathologique du système nerveux. Prog Med 1879:258-259.

75. Charcot JM. De la suspension dans le traitement de l'ataxie locomotrice progressive et quelques autres maladies du système nerveux. Prog Med 1889;9:50-51.

76.Charcot JM. La foi qui guérit. Paris: Aux Bureaux du Progrès Médical; 1897.

77.69. Charcot JM, Blin E, Charcot JB, Colin H. Leçons du mardi à la Salpêtrière :

policliniques, 1887-1888. Paris: Bureaux du Progrès Médical; 1887.

78.70. Charcot JM, Bouchard C, Brissaud É, et al. Traité de médecine. Paris: G. Masson; 1891.

79.71. Charcot JM, Bourneville DM. Leçons sur les maladies du système nerveux : faites à la Salpêtrière. Paris: Adrien Delhaye; 1872.

80.72. Charcot JM, Bourneville DM. Leçons sur les localisations dans les maladies du cerveau : faites à la faculté de Médecine de Paris (1875). Paris: Adrien Delahaye; 1876.

81.73. Charcot JM, Joffroy A. Deux cas d'atrophie musculaire progressive : avec lésions de la substance grise et des faisceaux antéro-latéraux de la moelle épinière. Arch Physiol Neurol Pathol 1869;2: 357-367, 629-650, 745-760.

82.74. Charcot JM, Marie P. Deux nouveaux cas de sclérose latérale amyotrophique. Arch Neurol 1885;10:1-35,168-186.

83.75. Charcot JM, Marie P. Sur une forme particulière d'atrophie musculaire progressive souvent familiale débutant par les pieds et les jambes et atteignant plus tard les mains. Rev Med 1886;6:97-138.

84.76. Charcot JM, Pitres A. Contribution à l'étude des localisations dans

l'écorce des hémisphères du cerveau. Observations relatives aux paralysies et aux

convulsions d'origine corticale. Revue Mensuelle de Médecine et de Chirurgie 1877;1:1-18, 113-123, 180-195, 357-376, 437-457 .

85.77. Charcot JM, Pitres A. Nouvelle contribution à l'étude des localisations 
motrices dans l'écorce des hémisphères du cerveau. Revue Mensuelle de Médecine et de Chirurgie 1878;2:801-815.

86.78. Charcot JM, Pitres A. Nouvelle contribution à l'étude des localisations

motrices dans l'écorce des hémisphères du cerveau. Revue Mensuelle de Médecine et de Chirurgie 1878;3:127-156.

87.79. Charcot JM, Pitres A. Étude critique et clinique de la doctrine des localisations motrices dans l'écorce des hémisphères cérébraux de l'homme. Rev Méed 1883;3:329-354, 425-468, 844-887.

88.80. Charcot JM, Pitres A. Les centres moteurs corticaux chez l'homme. Paris: Rueff; 1895 .

89.81. Charcot JM, Richer P. Les démoniaques dans l'art. Paris: Delahaye et Lecrosnier; 1887.

90.82. Charcot JM, Richer P. Le mascaron grotesque de l'église Santa Maria Formosa, à Venise, et l'hémispasme glosso-labié hystérique. Nouvelle Iconographie de la Salpêtrière $1888 ; 1: 87-92$.

91.83. Charcot JM, Richer P. Les difformes et les malades dans l'art. Paris: Lecrosnier et Babé; 1889.

92.84. Charcot JM, Richer P. Les malades dans l'art. Paris: Masson; 1900.

93.85. Charcot JM, Vulpian A. De la paralysie agitante : à propos d'un cas tiré de la clinique du professeur Oppolzer. Paris: Masson; 1862.

94.86. Charcot JM, Vulpian A. Sur deux cas de sclérose des cordons postérieurs de la moelle avec atrophie des racines postérieures (tabes dorsalis, Romberg, ataxie locomotrice progressive, Duchenne de Boulogne). C R Séances Mém Soc Biol 1862;4:155-173. 95.87. Charcot JM, Vulpian A. Sur un cas d'atrophie des cordons postérieurs de la moelle épinière et des racines postérieures. Paris: A. Delahaye; 1862.

96.88. Chudley AE. Genetic landmarks through philately: Georges Marinesco (1863-1938). Clin Genet 2003;64:297-299.

97.89. Clanet M. Jean-Martin Charcot. 1825 to 1893. Int MS J 2008;15:59-61.

98.90. Clarac F, Massion J, Smith AM. Duchenne, Charcot and Babinski, three neurologists of La Salpêtrière Hospital, and their contribution to concepts of the central organization of motor synergy. J Physiol Paris 2009;103:361-376.

99.91. Cohen H. Pierre Marie 1853-1940. Proc R Soc Med 1953;46:1047-1054.

100.Cohen SG. Asthma among the famous. Armand Trousseau (1801-1867), French physician. Allergy Asthma Proc 1997;18:40-42.

101.92. Collière MF. Le legs de Désiré Bourneville à la profession infirmière. Soins 1999;(639):18-20.

102.93. Colosimo C, Berardelli A. An early image of hemifacial spasm: Édouard Brissaud contribution. Mov Disord 2010; 25: 531-533.

103.94. Cousin MT. Vulpian and not Claude Bernard first proposed the hypothesis of the motor end-plate as the site of action of curare. Anesthesiology 2002;97:527-528.

104.95. Cuthbertson RA. Duchenne de Boulogne. Aust N Z J Surg 1979;49:275-278.

105.96. Cuthbertson RA. Duchenne de Boulogne and human facial expression. Clin Exp Neurol 1985;21:55-67.

106.97. Cuthbertson RA, Hueston JT. Duchenne de Boulogne and clinical photography. Ann Plast Surg 1979;2:332-337.

107.98. Darwin C. L'expression des émotions chez l'homme et les animaux. Paris: C. Reinwald; 1874.

108.99. De Ajuriaguerra J. L'œuvre scientifique du docteur André-Thomas. Rev Neurol (Paris) 1955;93:1-28. 
109.Dejerine J. Recherches sur les lésions du système nerveux dans la paralysie ascendante aiguë. Paris: Aux Bureaux du Progrès Médical; 1879.

110.Dejerine J. L'hérédité dans les maladies du système nerveux. Paris: Asselin et Houzeau; 1886.

100. Dejerine J. Contribution à l'étude anatomo-pathologique et clinique des différentes variétés de cécité verbale. Mem Soc Biol. 1892;44:61-90.

111.101. Dejerine J. Sémiologie des affections du système nerveux. Paris: Masson; 1914.

112.102. Dejerine J, Deéjerine-Klumpke A. Anatomie des centres nerveux. Paris: Rueff; 1895.

113.103. Dejerine J, Gauckler E. Les manifestations fonctionnelles des psychonévroses, leur traitement par la psychothérapie. Paris: Masson; 1911.

114.104. Dejerine J, Roussy G. Le syndrome thalamique. Rev Neurol (Paris) 1906;12:521-532.

115.105. Dejerine J, Sottas J. Sur la névrite interstitielle, hypertrophique et progressive de l'enfance. C R Soc Biol 1893;45:63-96.

116.106. Dejerine J, Thomas A. L'atrophie olivo-ponto-cérébelleuse. Nouvelle Iconographie de la Salpêtrière 1900;13:330-370.

117.107. Dejerine J, Thomas A. Traité des maladies de la moelle épinière : avec 162 figures intercalées dans le texte. Paris: J.-B. Baillière et Fils; 1902.

118.Dejerine J, Thomas A. Les lésions des racines, des ganglions rachidiens et des nerfs dans un cas de maladie de Friedrich, examen par la méthode de Ramon Y Cajal (imprégnation à l'argent). Rev Neurol (Paris) 1907;15:41-54.

119.108. Dejerine-Klumpke A. Des polynévrites en général et des paralysies et atrophies saturnines en particulier : étude clinique et anatomo-pathologique. Thèse de médecine : Paris; 1889.

120.109. Dejerine-Klumpke A. Paralysie radiculaire totale ou plexus brachial avec phénomènes oculo-pupillaire. Paris: Masson; 1908.

121.110. Dejerine-Klumpke A, Jumentié J. Contribution à l'étude des fibres aberrantes de la voie pédonculaire dans son trajet pontin. Les faisceaux aberrants bulbo-protubérantiels internes et externes. Fascicules aberrants médio-pontins. Pes lemniscus interne. Rev Neurol (Paris) 1910;20:385-398.

122.111. Dellon ES, Dellon AL. The first nerve graft, Vulpian, and the nineteenth century neural regeneration controversy. J Hand Surg Am 1993;18:369-372.

123.112. Djaldetti R, Mosberg-Galili R, Sroka H, Merims D, Melamed E.

Camptocormia (bent spine) in patients with Parkinson's disease-characterization and possible pathogenesis of an unusual phenomenon. Mov Disord 1999;14: 443-447.

124.113. Duchenne G. De l'électrisation localisée et de son application à la physiologie, à la pathologie et à la thérapeutique. Paris: J.-B. Baillière; 1855.

125.114. Duchenne G. De l'ataxie locomotrice progressive. Recherches sur une maladie caractérisée spécialement par des troubles généraux de la coordination des mouvements. Arch Gen Med 1858;12:641-652.

126.115. Duchenne G. Album de photographies pathologiques complémentaires du livre intitulé de l'électrisation localisée. Paris: J.-B. Baillière; 1862.

127.116. Duchenne G. Mécanisme de la physionomie humaine, ou, Analyse électrophysiologique de l'expression des passions. Paris: Renouard; 1862.

128.117. Duchenne G. Physiologie des mouvements démontrée à l'aide de l'expérimentation électrique et de l'observation clinique et applicable à l'étude des paralysies et des déformations. Paris: J.-B. Baillière et fils; 1867. 
129.118. Duchenne G. Recherches sur la paralysie musculaire pseudo-hypertrophique ou paralysie myosclérotique. Arch Gen Med 1868;11:5-25, 179-209, 305-321, 421-443, 552-588. 130.Duchenne G. Studies on pseudohypertrophic muscular paralysis or myosclerotic paralysis. Arch Neurol 1968;19:629-636.

131.119. Duckett S. André-Thomas (1867-1963). J Neurol 2000;247:235-236.

132.Dunn PM. Professor Armand Trousseau (1801-67) and the treatment of rickets. Arch Dis Child Fetal Neonatal Ed 1999;80:F155-F157.

133.120. Ellis H. Augusta Klumpke (1859-1927). J Neurol 2011;257:1765-1766.

134.121. Faber DP. Jean-Martin Charcot and the epilepsy/hysteria relationship. J Hist Neurosci 1997;6:275-290.

135.122. Ferrell AS, Tubbs RS, Acakpo-Satchivi L, Deveikis JP, Harrigan MR. Legacy and current understanding of the often-misunderstood Foix-Alajouanine syndrome. Historical vignette. J Neurosurg 2009;111:902-906.

136.123. Foix C. Les troubles sensitifs au cours de l'hémiplégie-aphasie. Rev Neurol (Paris) 1911;2:61-71.

137.124. Foix C. Les lésions anatomiques de la maladie de Parkinson. Rev Neurol (Paris) 1921;28:593.

138.125. Foix C, Alajouanine T. La myélite nécrotique subaiguë. Myélite centrale angéio-hypertrophique à évolution progressive. Paraplégie amyotrophique lentement ascendante, d'abord spasmodique, puis flasque, s'accompagnant de dissociation albuminocytologique. Rev Neurol (Paris) 1926;46:1-42.

Foix C, Chavany J, Hillemand P, Schiff-Wertheimer S. Oblitération de l'artère choroidienne antérieure: ramollissement de son territoire cérébral: hémiplégie, hémianesthésie, hémianopsie. Bull Soc Ophtalmol Paris 1925;37:221-223.

126.

127. Foix, C, Chavany, JA, Marie, J. Diplégie facio-linguo-masticatrice d'origine cortico sous-corticale sans paralysie des membres. Rev Neurol (Paris) 1926;1:214-219.

140.128. Foix C, Hillemand P. Spasme rythmique vélopharyngolaryngé. Nystagmus du voile. Rev Neurol (Paris) 1924;2:501-503.

141.129. Foix C, Hillemand P. Irrigation de la protubérance. C R Soc Biol 1925;92:35-

36.

142.130. Foix C, Hillemand P. Les artères de l'axe encéphalique jusqu'au diencéphale inclusivement. Rev Neurol (Paris) 1925;41:705-739.

143.131. Foix C, Hillemand P. Les syndromes de la région thalamique. Presse Méed 1925;33:113-117.

144.132. Foix C, Hillemand P. Les syndromes de l'artère cérébrale antérieure.

Encéephale 1925;20:209.

144.Foix C, Marie J. La sclérose cérébrale centro-lobaire à tendance symétrique. Ses rapports avec l'encéphalite périaxiale diffuse. Encephale 1927;22:81-126.

146.133. Foix C, Masson A. Les syndromes de l'artère cérébrale postérieure. Presse Méed 1923;31:361-365.

147.134. Foix C, Nicolesco J. Anatomie cérébrale : les noyaux gris centraux et la région mésencéphalo-sous-optique ; suivie d'un appendice sur l'anatomie pathologique de la maladie de Parkinson. Paris: Masson; 1925.

147.Foix C, Salin H. De l'hémoglobinurie globulaire expérimentale: (contribution à l'étude de l'hémoglobinurie paroxystique). Paris: Masson; 1912.

135. Freeman W. Edouard Brissaud (1852-1909). In: Webb Haymaker, MD eds. The Founders of Neurology. Springfield, Illinois, USA: Charles Thomas Publisher; 1953: 257259. 
148.Furukawa T. Classics in neurology. Congenital facioscapulohumeral muscular dystrophy described by Duchenne in 1862. Neurology 1984;34:647.

150.136. Gasecki AP, Kwieciński H. On the legacy of Joseph Babinski. Eur Neurol 1995;35:127-130.

151.137. Gelfand T, Goetz CG, Colomb M. Charcot, un grand médecin dans son siècle. Paris : Michalon; 1996.

152.138. Gilles de la Tourette G. Étude sur une affection nerveuse caractérisée par de l'incoordination motrice accompagnée d'écholalie et de coprolalie (jumping, latah, and myriachit). Arch Neurol 1885;9:19-42, 158-200.

153.139. Gilles de la Tourette. Etudes cliniques et physiologiques sur la marche: la marche dans les maladies du système nerveux étudiée par la méthode des empreintes. Paris: Delahaye et Lecrosnier; 1886.

154.140. Brouardel Gilles de la Tourette G. L'hypnotisme et les états analogues au point de vue médico-légal. Paris: Plon; 1887.

155.141. Gilles de la Tourette G, Hôpital de la Salpêtrière (Paris). Traité clinique et thérapeutique de l'hystérie d'après l'enseignement de la Salpêtrière. Paris: Plon, Nourrit; 1891. 156.142. Gilles de la Tourette G. Leçons de clinique thérapeutique sur les maladies du système nerveux. Paris: E. Plon, Nourrit; 1898.

157.143. Gilles de la Tourette G. La maladie des tics convulsifs. Semaine Med 1899;19:153-156.

158.144. Goetz CG. History of the extensor plantar response: Babinski and Chaddock signs. Semin Neurol 2002;22:391-398.

158.Goetz CG. Jean-Martin Charcot and the aging brain. Arch Neurol 2002;59:1821-1824.

160.145. Goetz CG. Pierre Marie: gifted intellect, poor timing and unchecked emotionality. J Hist Neurosci 2003;12:154-166.

161.146. Goetz CG. J.-M. Charcot and simulated neurologic disease: attitudes and diagnostic strategies. Neurology 2007;69:103-109.

161.Goetz CG. Jean-Martin Charcot and his vibratory chair for Parkinson disease. Neurology 2009;73:475-478.

163.147. Goetz CG, Bonduelle M, Gelfand T. Charcot: constructing neurology. New York: Oxford Univ. Press; 1995.

164.148. Goetz CG, Chmura TA, Lanska DJ. History of tic disorders and Gilles de la Tourette syndrome: Part 5 of the MDS-sponsored history of movement disorders exhibit, Barcelona, June 2000. Mov Disord 2001;16:346-349.

164.Goetz CG, Chmura TA, Lanska DJ. Seminal figures in the history of movement disorders: Gilles de la Tourette, Oppenheim, the Vogts, von Economo, Wilson, and Marsden. Part 12 of the MDS-sponsored History of Movement Disorders exhibit, Barcelona, June 2000. Mov Disord 2001;16:940-946.

166.149. Goetz CG, Klawans HL. Gilles de la Tourette on Tourette syndrome. Adv Neurol 1982;35:1-16.

167.150. Guillain G. Les polyradiculonevrites avec dissociation albumiambinocytologique et à évolution favorable (syndrome de Guillain-Barré). J Belg Neurol Psychiatr 1938;38:323-329.

168.151. Guillain G. J.-M. Charcot : 1825-1893 : sa vie, son oeuvre. Paris: Masson; 1955.

169.152. Guillain G, Barré JA. Travaux neurologiques de guerre. Paris: Masson; 1920. 153. Guillain G, Barré JA, Strohl A. Sur un syndrome de radiculonévrite avec hyperalbuminose du liquide céphalo-rachidien sans réaction cellulaire. Remarques sur les caractères cliniques et graphiques des réflexes tendineux. Bull Soc Méed Hop Paris 1916;40:1462-1470. 
170.154. Guillain G, Bertrand I. Anatomie topographique du système nerveux central. Paris: Masson; 1926.

171.155. Guillain G, Laroche G, Léchelle P. La réaction du benjoin colloïdal et les réactions colloïdales du liquide céphalorachidien. Paris: Masson; 1922.

172.156. Guillain G, Laroche G, Léchelle P. Technique de la réaction du benjoin colloïdal. Paris: Masson et Cie; 1926.

173.157. Guillain G, Mathieu P. La Salpêtrière. Paris: Masson; 1925.

174.158. Guillain G, Mollaret P. Deux cas de myoclonies synchrones et rythmées vélopharyngo-oculo-diaphragmatiques. Le problème anatomique et physio-pathologique de ce syndrome. Rev Neurol (Paris) 1931;2:545-566.

175.159. Guillain G, Mollaret P. Études neurologiques. Septième série, Les myoclonies vélo-pharyngo-laryngo-oculo-diaphragmatiques, la maladie de Friedreich, pathologie du névraxe. Paris: Masson; 1936.

176.160. Guillain G, Thurel R, Bertrand I. Examen anatomopathologique d'un cas de myoclonies vélo-pharyngo-oculodiaphragmatiques associées à des myoclonies squelettiques synchrones. Rev Neurol (Paris) 1933;2:801-812.

177.161. Hécaen MH, Bonduelle M. La vie et l'oeuvre d'André Thomas. Rev Neurol (Paris) 1967;116:461-466.

178.162. Henderson VW. Jules Dejerine and the third alexia. Arch Neurol 1984;41:430432.

179.163. Hillemand P. Charles Foix et son oeuvreœuvre, 1882-1927. Clio Med 1976;11:269-287.

180.164. Hueston JT, Cuthbertson RA. Duchenne de Boulogne and facial expression. Ann Plast Surg 1978;1:411-420.

181.165. Jay V. On a historical note: Duchenne of Boulogne. Pediatr Dev Pathol 1998;1:254-255.

182.166. Klumpke A. Contribution à l'étude des paralysies radiculaires du plexus brachial, paralysies radiculaires totales, paralysies radiculaires inférieures. De la participation des filets sympathiques oculo-pupillaires dans ces paralysies. Rev Méed 1885;5:591-616, 739-790.

183.167. Konofal E, Karroum E, Montplaisir J, Derenne J, Arnulf I. Two early descriptions of restless legs syndrome and periodic leg movements by Boissier de Sauvages (1763) and Gilles de la Tourette (1898). Sleep Med 2009;10:586-591.

184.168. Krämer H, Daniels C. Pioneers of movement disorders: Georges Gilles de la Tourette. J Neural Transm 2004;111:691-701.

185.169. Lajonchere C, Nortz M, Finger S. Gilles de la Tourette and the discovery of Tourette syndrome. Includes a translation of his 1884 article. Arch Neurol 1996;53:567-574. 186.170. Lance JW. The Babinski sign. J Neurol Neurosurg Psychiatry 2002;73:360362.

187.171. Landouzy L, Dejerine J. De la myopathie atrophique progressive, myopathie sans neuropathie, débutant d'ordinaire dans 1"enfance la face. Rev Méed 1885;5:81-117, 253 366.

188.172. Lebrun Y. Portraits in aphasia: Armand Trousseau (1801-1867). Eur J Disord Commun. 1993;28:103-108.

189.173. Lecours AR, Caplan D. Augusta Dejerine-Klumpke or "The Lesson in Anatomy". Brain Cogn 1984;3:166-197.

190.174. Lees AJ. Georges Gilles de la Tourette. The man and his times. Rev Neurol (Paris) 1986;142:808-816.

190.Legent F. Armand Trousseau, laryngologiste. Hist Sci Méd 2007;41:83-94. 
192.175. Lhermitte J. L'école de la Salpêtrière : J.M. Charcot, psycho-physiologiste. Encephale $1950 ; 2002 ; 2839: 49-57297-310$.

192.Lisowski W. Professor Józef Babinski (1857-1932) - pioneer of contemporary classical neurology. Mater Med Pol 1986;18:179-182.

194.176. Lorch MP, Barrière I. The history of written language disorders: Reexamining Pitres' case (1884) of pure agraphia. Brain Lang 2003;85:271-279.

194.Lyons JB. Pioneers in medicine: Josef Babinski; 1857-1932. Nurs Mirror Midwives J 1975;141:53.

196.177. Lyons JR. Pioneers in medicine: Armand Trousseau (1801-1867). Nurs Mirror Midwives J 1976;143:58.

197.178. Marie P. Contribution à l'étude et au diagnostic des formes frustes de la maladie de Basedow. Thèse de médecine: Paris; 1883.

198.179. Marie P. Sur deux cas d'acromégalie. Rev Méed 1886;6:297-299.

199.180. Marie P. De l'ostéo-arthropathie hypertrophiante pneumique. Rev Med Méd 1890;10:1-36.

200.181. Marie P. Sur l'hérédo-ataxie cérébelleuse. Semaine Méed 1893;13:444-447.

201.182. Marie P. Sur la spondylose rhizomélique. Rev Méed 1898;18:285.

202.183. Marie P. Révision de la question de l'aphasie: que faut-il penser des aphasies sous-corticales (aphasies pures)? Semaine Méed 1906;23:493-500.

203.184. Marie P, Foix C. Les aphasies de guerre. Rev Neurol (Paris) 1917;24:53-97.

204.185. Marie P, Foix C, Alajouanine T. De l'atrophie cérébelleuse tardive à prédominance corticale. Rev Neurol (Paris) 1922;29:849-1082.

205.186. Marie P, Santon P. Sur la dysostose cléidocrânienne héréditaire. Rev Neurol (Paris) 1898;6:835-838.

205.Marie P, Sergent É, Ribadeau-Dumas L, Babonneix L. Traité de pathologie médicale et de thérapeutique appliquée. Paris: Maloine; 1921.

207.187. Marinesco G. De la destruction de la glande pituitaire chez le chat. C R

Séeances Soc Biol Fil 1892;44:509-510.

208.188. Marinesco G. Lésions des neuro-fibrilles dans certains états pathologiques. C R Soc Biol 1905; 12:536-538.

209.189. Marinesco G. Sur la réparation des neuro-fibrilles après la section du nerf hypoglosse. Rev Neurol (Paris) 1905;5:5-16.

210.190. Marinesco G. La cellule nerveuse. Paris: O. Doin et fils; 1909.

211.191. Marinesco G. Sur la structure des plaques dites séniles dans l'écorce cérébrale des sujets atteints d'affections mentales. C R Séeances Soc Biol Fil. 1911;70:609.

211.Marinesco G. Sur la structure colloïdale des cellules nerveuses et ses variations à l'état normal et pathologique. Bruxelles : Rapport extrait du 3ème congrès international de neurologie; 1913.

213.192. Marinesco G. The characteristics of amputation neuromata. Proc R Soc Med 1918;11:5.2-6.2.

214.193. Marinesco G. Recherches anatomo-cliniques sur les névromes d'amputations douloureux. Nouvelles contributions à l'étude de la Régéneration nerveuse et du neurotropisme. Philos Trans R Soc Lond B Biol Sci 1920;209:229-304.

214.Marinesco G. Du mécanisme physico-chimique des lésions de la sclérose latérale amyotrophique. Rev Neurol (Paris) 1922;38:161-170.

216.194. Marinesco G. Recherches sur les plaques séniles. Bull Sect Scient de l'Acad Roumaine 1928;7-8:1.

216. Marinesco G, Draganesco S, Grigoresco G. Sur un cas de parkinsonisme postencéphalitique survenu chez un ancien poliomyélitique. Rev Neurol (Paris) 1929;45:102140 . 
218.195. Marinesco G, Draganesco S, Stoicesco. Sur une variété spéciale de paraplégie spasmodique familiale caractérisée par des crises paroxystiques d'hypertonie, probablement d'origine extra-pyramidale, et par des troubles végétatifs. Encéephale 1925;20:645-654.

218. Marinesco G, Nicolesco J. Un cas de parkinsonisme accompagné de crises oculogyres et d'hallucinations colorées. Rev Neurol (Paris) 1932;48:691-693.

219.Marinesco G, Tretiakoff C. Etude histo-pathologique des centres nerveux dans trois cas de maladie de Friedreich. Rev Neurol (Paris) 1920;36:113-131.

221.196. Massie R. Charcot et Babinski: au-delà de la simple relation professeur-élève. Can J Neurol Sci 2004;31:422-426.

222.197. Mayer J. Armand Trousseau and the arrow of time. Nutr Rev 1957;15:321-323.

223.198. Mollaret P. Georges Guillain (1876-1961). Presse Méed 1961;69:1695-1696.

224.199. Moreau R. Hommage à la mémoire de Josef Babinski à l'occasion du 100ème anniversaire de sa naissance. Bull Méem Soc Méed Hôop Paris 1958;74:449-450.

225.200. Nelson KR, Genain C. Vignette. Duchenne de Boulogne and the muscle biopsy. J Child Neurol 1989;4:315.

226.201. Ostini S. La faradisation selon Duchenne de Boulogne (1855). Rev Méed Suisse Romande 1993;113:245-246.

227.202. Ouvrier R. Henri Parinaud and his syndrome. Med J Aust 1993;158:711, 714.

228.203. Parent A. Duchenne de Boulogne (1806-1875). Parkinsonism Relat Disord 2005;11:411-412.

229.204. Parent A. Duchenne De Boulogne: a pioneer in neurology and medical photography. Can J Neurol Sci 2005;32:369-377.

230.205. Parinaud H. Étude sur la névrite optique dans la méningite aiguë de l'enfance. Paris: J. B. Baillière et fils; 1877.

231.206. Parinaud H. Spasme et paralysie des muscles de l'oeil. Paris: C. Masson; 1877. 231.Parinaud H. De la polyopie monoculaire dans l'hystérie. Gand: I.S. Van Doosselaere; 1878.

233.207. Parinaud H. Atrophie des nerfs optiques dans l'érysipèle de la face. Paris:

Asselin; 1879.

234.208. Parinaud H. De la névrite optique dans les affections cérébrales. Gand: J. S.

Van Doosselaere; 1879.

235.209. Parinaud H. Paralysie de la convergence. Ann Ocul 1886;95:205-6.

236.210. Parinaud H. Échelle optométrique : Acuité visuelle. Perception de la lumière et des couleurs. Paris: E. Giroux; 1888.

237.211. Parinaud H. Conjonctivite infectieuse transmise par les animaux. Ann Ocul 1889;101:252-253.

238.212. Parinaud H. Rapport sur le traitement du strabisme. Paris: congrès de la Société Française d'Ophtalmologie; 1893.

239.213. Parinaud H. La vision : étude physiologique. Paris: Doin; 1898.

240.214. Pearce JM. The thalamic syndrome of Dejerine and Roussy. J Neurol

Neurosurg Psychiatry 1988;51:676.

241.215. Pearce JM. Some contributions of Duchenne de Boulogne (1806-75). J Neurol Neurosurg Psychiatry 1999;67:322.

242.216. Pearce JM. Armand Trousseau -- some of his contributions to neurology. J Hist Neurosci 2002;11(2):125-135.

243.217. Pearce JM. Edmé Félix Alfred Vulpian (1826-1887). J Neurol 2002;249:17491750.

243.Pearce JM. Charcot on "provoked trepidation", or clonus. J Neurol Neurosurg Psychiatry 2003;74:1277. 
245.218. Pearce JM. A note on Pierre Marie (1853-1940). J Neurol Neurosurg Psychiatry 2004;75:1583.

246.219. Pearce JM. Primary lateral sclerosis and Pierre Marie. J Neurol Neurosurg Psychiatry 2004;75:897.

247.220. Pearce JM. A note on aphasia in bilingual patients: Pitres' and Ribot's laws. Eur Neurol 2005;54:127-131.

248.221. Petresco A. Gheorghe Marinesco (1863-1963), promoteur de l'histochimie du système nerveux (A l'occasion du centenaire de sa naissance, 1963). Ann Histochim 1964;9:145-153.

249.222. Peumery J. Armand Trousseau (1801-1867), médecin français par excellence. Hist Sci Méd. 2003;37(2):151-156.

250.223. Philippon J, Poirier J. Joseph Babinski. A biography. New York: Oxford University Press; 2009.

251.224. Pitres A. Recherches sur les lésions du centre ovale des hémisphères cérébraux étudiées au point de vue des localisations cérébrales. Thèse de médecine : Paris; 1877.

252.225. Pitres A. Considérations sur l'agraphie. Rev Méed 1884;4:855-873.

253.226. Pitres A. Sur quelques troubles vaso-moteurs et sécrétoires qui peuvent survenir au début de l'ataxie locomotrice progressive. Bordeaux: G. Gounouilhou; 1884. 253.Pitres A, Bitot É. Da Hemiplegia syphilitica. Paris: G. Steinheil; 1889.

255.227. Pitres A. Leçons cliniques sur l'hystérie et l'hypnotisme : faites à l'hôpital Saint-André de Bordeaux. Paris: Doin; 1891.

256.228. Pitres A. Rapport sur la question des aphasies. Congrès français de médecine interne (Session de Lyon). Bordeaux: Gounouilhou; 1894.

257.229. Pitres A. Étude sur l'aphasie chez les polyglottes. Rev Méed 1895;15:873-899. 257.Pitres A. Étude sur les sensations illusoires des amputés. Année Psychol 1897;4:542-546. 259.230. Pitres A. L'aphasie amnésique et ses variétés cliniques. Leçons faites à 1'hôpital Saint André de Bordeaux. Prog Med 1898;7:321-324, 337-341, 369-372, 401-405. 259.Pitres $\mathrm{A}$. La lutte antituberculeuse à Bordeaux et dans la région, organisation et fonctionnement. Bordeaux: Librairie de la Mutualité; 1906.

Pitres A, Bitot É. Da Hemiplegia syphilitica. Paris: G. Steinheil; 1889.

261.231. Poirier J. Joseph Babinski: une personnalité complexe. Bull Acad Natl Méed 2007;191:1343-1353; discussion 1353-1354.

262.232. Poirier J. Babinski, histologist and anatomo-pathologist. Rom J Morphol Embryol 2008;49:263-269.

263.233. Poirier J. Édouard Brissaud, un neurologue d'exception dans une famille d'artistes. Paris: Hermann; 2010.

234. Poirier J. Édouard Brissaud (1852-1909). J Neurol 2011;258 :951-952.

264.235. Poirier J, Chrétien F. Désiré Bourneville (1840-1909). J Neurol 2000;247:481.

265.236. Poirier J, Chrétien F. Pierre Marie (1853-1940). J Neurol 2000;247:983-984.

266.237. Poirier J, Signoret JL. De Bourneville à la sclérose tubéreuse. Paris:

Flammarion Médecine-Sciences; 1991.

267.238. Poirier J, Signoret JL. Note historique: Désiré Bourneville (1840-1909). Rev

Neurol (Paris) 1991;147:705.

268.239. Poisson M. Désiré Magloire Bourneville (1840-1909). Rev Infirm 2008;(144):45.

269.240. Polonovski J. Hommage au Professeur J.-André Thomas (1905-1999). J Soc Biol 1999;193:443-444.

270.241. Rascol A, Clanet M. La sclérose en plaques. De Charcot et Vulpian à nos jours. Rev Neurol (Paris) 1982;138:921-930. 
271.242. Reincke H, Nelson KR. Duchenne de Boulogne: electrodiagnosis of poliomyelitis. Muscle Nerve 1990;13:56-62.

271.Reubi FC. Armand Trousseau (1801-1867) et l'effet placebo. Schweiz Med Wochenschr 1986;116:27-28.

273.243. Reyre G. Bourneville: "une tentation d'emprise de l'aliénisme sur le champ scolaire". Soins Psychiatr 1989;(104-105):55-59.

274.244. Richer P. Anatomie artistique: description des formes extérieures du corps humain au repos et dans les principaux mouvements. Paris: Plon \& Nourrit; 1890.

275.245. Richer P. Paralysies et contractures hystériques. Paris: Doin; 1892.

276.246. Richer P. Nouvelle anatomie artistique du corps humain. I, Cours pratique.

Eléments d'anatomie. L'homme. Paris: Plon-Nourrit; 1920.

277.247. Richer P. Nouvelle anatomie artistique du corps humain. II, Cours supérieur.

Morphologie. La femme. Paris: Plon-Nourrit; 1920.

278.248. Richer P, Meige H. Étude morphologique sur la maladie de Parkinson.

Nouvelle Iconographie de la Salpêtrière 1895;8:361-371.

279.249. Rickards H, Cavanna AE. Gilles de la Tourette: the man behind the syndrome. J Psychosom Res 2009;67:469-474.

280.250. Rickards H, Woolf I, Cavanna AE. "Trousseau's disease". A description of the Gilles de la Tourette syndrome 12 years before 1885. Mov Disord 2010;25:2285-2289.

251. Roch Lecours A. Aphasie : querelles. Rev Neurol (Paris) 1999;150: 833-847.

281.252. Rondot P. G. B. A. Duchenne de Boulogne (1806-1875). J Neurol 2005;252:866-867.

282.253. Ryckewaert A, Naveau B. Principaux apports de Charcot et de Pierre Marie à la pathologie ostéo-articulaire. Rev Rhum Mal Osteoartic 1984;51:405-413.

282.Sanders LJ. Jean-Martin Charcot (1825-1893). The man behind the joint disease. J Am Pediatr Med Assoc 2002;92:375-380.

284.254. Satran R. Augusta Dejerine-Klumpke. First woman intern in Paris hospitals. Ann Intern Med 1974;80:260-264.

285.255. Schurch B, Dollfus P. The 'Dejerines': an historical review and homage to two pioneers in the field of neurology and their contribution to the understanding of spinal cord pathology. Spinal Cord 1998;36:78-86.

286.256. Shoja MM, Tubbs RS. Augusta Deéjerine-Klumpke: the first female neuroanatomist. Clin Anat 2007;20:585-587.

287.257. Sigwald J. Hommage à André Thomas. Rev Neurol (Paris) 1967;116:457-460. 288.258. Simonetti F, Pergami P, Ceroni M, Ropper AH, Viviani R. About the original description of cerebellar tonsil herniation by Pierre Marie. J Neurol Neurosurg Psychiatry 1997;63:412.

289.259. Skalski JH. Joseph Jules François Félix Babinski (1857-1932). J Neurol 2007;254:1140-1141.

290.260. Skidmore F, Anderson K, Fram D, Weiner W. Psychogenic Camptocormia. Mov Disord 2007; 22: 1974-1975.

291.261. Société Française de Neurologie. Achille Souques (1860-1944). Rev Neurol (Paris) 1945;77: 3-6.

292.262. Soriano V. André Thomas. Int J Neurol 1967;6:222-226.

293.263. Souques A. Palilalie. Rev Neurol (Paris) 1908;16:340-342.

294.264. Souques A. Rapports sur les syndromes parkinsoniens. Rev Neurol (Paris) 1921;37:534-715.

295.265. Souques A. Les étapes de la neurologie dans l'Antiquité grecque (d'Homère à Galien). Paris: Masson; 1936. 
296.266. Souques A, Rosanoff-Saloff. La camptocormie; incurvation du tronc consécutive au traumatisme du dos et des lombes; considérations morphologiques. Rev Neurol (Paris) 1914-1915;22:937-939.

297.267. Stevens H. Gilles de la Tourette and his syndrome by serendipity. Am J Psychiatry 1971;128:489-492.

298.268. Tan SY, Shigaki D. Jean-Martin Charcot (1825-1893): pathologist who shaped modern neurology. Singapore Med J 2007;48:383-384.

299.269. Tatu L. Édouard Brissaud, Fulgence Raymond and the Succession of Charcot. Front Neurol Neurosci 2011;29:52-60.

300.270. Tatu L, Moulin T, Monnier G. The discovery of encephalic arteries. From Johann Jacob Wepfer to Charles Foix. Cerebrovasc Dis 2005;20:427-432.

300.Teive HAG, Munhoz RP, Barbosa ER. Little-known scientific contributions of J-M Charcot. Clinics (Sao Paulo) 2007;62:211-214.

302.271. Thomas A. Le cervelet : étude anatomique, clinique et physiologique. Paris: G. Steinheil; 1897.

303.272. Thomas A. Syndrome cérébelleux et syndrome bulbaire. Rev Neurol (Paris). 1905; 13:16-24.

304.273. Thomas A. La dyschronométrie cérébelleuse. Presse Med 1937;93:1643-1646. 305.274. Thomas A, De Ajuriaguerra JD. ÉEtude sémiologique du tonus musculaire. Paris: Flammarion; 1949.

306.275. Thomas A, Dejerine J, Durupt A. Localisations cérébelleuses. Paris: Vigot Frères, Éditeurs; 1914.

307.276. Thomas A, Jumentié. Sur la nature des troubles de la motilité dans les affections du cervelet. Rev Neurol (Paris) 1909;21:1309-1318.

308.277. Thomas A, Saint-Anne Dargassies S. Études neurologiques sur le nouveau-né et le jeune nourrisson. Paris: Masson; 1952.

309.278. Trousseau A. Clinique médicale de l'Hôtel-Dieu de Paris. Paris: J.-B. Baillière et fils; 1861.

310.279. Trousseau A, Belloc H. Traité pratique de la phitisie laryngée, de la laryngite chronique et des maladies de la voix. Paris: J.-B. Baillière; 1837.

310.Trousseau A, Bonnet A. Recherches sur l'application extérieure du cyanure de potassium dans le traitement des céphalalgies et des douleurs nerveuses de la face. Bulletin Général de Thérapeutique Médicale et Chirurgicale 1831;1:329-340.

312.280. Trousseau A, Pidoux H. Traité de thérapeutique et de matière médicale. Paris: Béchet Jeune; 1836.

313.281. Ulgen BO, Brumblay H, Yang LJS, Doyle SM, Chung KC. Augusta DéjerineKlumpke, M.D. (1859-1927): a historical perspective on Klumpke's palsy. Neurosurgery 2008;63:359-366; discussion 366-367.

314.282. Vulpian A. Essai sur l'origine de plusieurs paires des nerfs crâniens (3e, $4 \mathrm{e}, 5 \mathrm{e}$, $6 \mathrm{e}, 7 \mathrm{e}, 8 \mathrm{e}, 9 \mathrm{e}$ et $10 \mathrm{e})$. Thèse de Médecine: Paris;1853. $\mathrm{N}^{\circ}$ d'ordre : 170.

315.283. Vulpian A. Note sur la sclérose en plaques de la moelle épinière. Un Méed Prat Franc 1866;30:459-465.

316.284. Vulpian A. De l'influence de la faradisation localisée sur l'anesthésie de causes diverses (lésions encéphaliques, saturnisme, hystérie, zona). Paris: O. Doin; 1880.

317.285. Vulpian A, Brémond E. Leçons sur la physiologie générale et comparée du système nerveux : faites au Muséum d'Histoire Naturelle. Paris: Germer Baillière; 1866.

318.286. Walusinski O, Bogousslavsky J. Georges Gilles de la Tourette (1857-1904). J Neurol 2011;258:166-167.

319.287. Walusinski O, Duncan G. Living his writings: The example of neurologist G. Gilles de la Tourette. Mov Disord 2010;25: 2290-2295. 
320.288. Wechsler I, Jean-Martin Charcot (1825-1893). In: Haymaker W., Schiller F, editors. The Founders of neurology. Springfield, Illinois, USA: Charles Thomas Publisher; 1953. p. 420-424.

321.289. Yildirim FB, Sarikcioglu L. Augusta Dejerine-Klumpke (1859-1927) and her eponym. J Neurol Neurosurg Psychiatry 2008;79:102. 